\title{
Vaccination: Epidemiological Review
}

\author{
David S. Younger ${ }^{1,2}$ \\ ${ }^{1}$ Department of Neurology, Division of Neuroepidemiology, New York University Langone Medical Center, New York, USA \\ ${ }^{2}$ The College of Global Public Health, New York University, New York, USA \\ Email: david.younger@nyumc.org
}

How to cite this paper: Younger, D.S. (2017) Vaccination: Epidemiological Review. World Journal of Neuroscience, 7 , 55-65.

http://dx.doi.org/10.4236/wjns.2017.71006

Received: January 3, 2017

Accepted: January 22, 2017

Published: January 25, 2017

Copyright $\odot 2017$ by author and Scientific Research Publishing Inc. This work is licensed under the Creative Commons Attribution International License (CC BY 4.0).

http://creativecommons.org/licenses/by/4.0/

\begin{abstract}
The induction of host protective immunity is an important factor in the immunization against potentially fatal disease and emerging illnesses in the U.S. and global populations especially among immunologically susceptible naïve hosts. Vaccination programs need to be evaluated as regards their health and economic population benefit among indigenous at risk populations taking into account emerging pathologies defined by the sudden appearance of a pathogen in nature or in a region of the world. Global collaboration is a necessary aspect of vaccine-preventable diseases since even a small number of wildtype cases of eradicated diseases in one region of the world present opportunities for their re-emergence in geographically remote areas. This study is a step in the direction of understanding the epidemiologic aspects of vaccination.
\end{abstract}

\section{Keywords}

Vaccination, Childhood, Epidemiology, Public Health

\section{Introduction}

We are in an era of intense change in the exploration and understanding of the complexity of the human microbiome and the ecosystems that surround us [1]. While we are host to a myriad of microorganisms that have assembled into complex communities outnumbering the human body by a factor of 10 -fold providing many of the building blocks for shared immunity, there still exist certain pathogenic microorganisms that cause human and economic devastation, which if prevented by effective vaccination campaigns, could easily be converted into their eradication [1]. This chapter examines selected aspects of domestic and global vaccination.

\section{Historical Aspects}

In the past century, the health and life expectancy of persons residing in the 
United States (U.S.) increased by $>30$ years, with 25 years of the gain attributable to advances in public health [2]. Vaccination of the public in the U.S. is among the 10 major public health achievements of the twentieth century [2]. At the beginning of this century, infectious diseases were widely prevalent in the U.S. and took an enormous toll on the population. With few effective antimicrobial treatments and preventative measures available, the first vaccine against smallpox was not widely enough employed to eradicate the disease, causing 894 fatalities of 12,064 reported cases [1]. Vaccination against rabies, typhoid, cholera and plague, was not widely achieved used until the turn of the century. Vaccines have since been developed or licensed for 21 other diseases in the U.S., 13 of which were recommended by the Centers for Disease Control and Prevention (CDC) for use in all U.S. children [1] (Table 1).

National efforts to promote vaccines among eligible children began with the appropriation of federal funds for polio vaccination after introduction of the vaccine in 1955. Federal, state, and local governments and public and private healthcare providers have collaborated to develop and maintain the vaccine-delivery system in the U.S. [2] [3]. At the end of the 20th century, vaccination coverage exceeded $90 \%$ for three or more doses of diphtheria and tetanus

Table 1. CDC schedule of infant and childhood vaccinations ${ }^{1}$.

\begin{tabular}{|c|c|c|c|c|}
\hline VACCINE NAME & AGE AT $1^{\text {st }}$ DOSE & AGE AT $2^{\text {nd }}$ DOSE & AGE AT $3^{\text {rd }}$ DOSE & AGE AT $4^{\text {th }}$ DOSE \\
\hline Hepatitis B (HepB) & $\mathrm{B}$ & $1-2 \mathrm{~m}$ & $6-18 \mathrm{~m}$ & \\
\hline $\begin{array}{l}\text { Rotavirus (RV) RV1 (2 dose series); } \\
\text { RV5 (3 dose series) }\end{array}$ & 2 months & 4 months & 6 months & \\
\hline $\begin{array}{l}\text { Diphtheria, tetanus, \& acellular pertussis } \\
\text { (DTaP: }<7 \text { years) }\end{array}$ & 2 months & 4 months & 6 months & 15 - 18 months \\
\hline $\begin{array}{l}\text { Tetanus, diphtheria, \& acellular pertussis } \\
\text { (Tdap: }>7 \text { years) }\end{array}$ & Tdap $11-12$ years & & & \\
\hline Haemophilus influenzae type b5 (Hib) & 2 months & 4 months & 6 months & $12-15$ months \\
\hline Pneumococcal conjugate (PCV13) & 2 months & 4 months & 6 months & $12-15$ months \\
\hline Inactivated poliovirus (IPV: $<18$ years) & 2 months & 4 months & $6-18$ months & $4-6$ years \\
\hline Influenza (ILV; LAIV) 2 doses for some & $\begin{array}{c}6 \text { - } 18 \text { months } \\
\text { annual vaccination } \\
\text { (IIV only) } \\
1 \text { or } 2 \text { doses }\end{array}$ & $\begin{array}{c}2 \text { - } 8 \text { years } \\
\text { annual vaccination } \\
\text { (LAIV or IIV) } \\
1 \text { or } 2 \text { doses }\end{array}$ & $\begin{array}{c}8 \text { - } 18 \text { years } \\
\text { annual vaccination } \\
\text { (LAIV or IIV) } \\
1 \text { dose only }\end{array}$ & \\
\hline Measles, Mumps, Rubella (MMR) & $12-15$ months & $4-6$ years & & \\
\hline Varicella (VAR) & $12-15$ months & $4-6$ years & & \\
\hline Hepatitis A (HepA) & $\begin{array}{l}12-18 \text { months } \\
\text { (2 dose series) }\end{array}$ & & & \\
\hline $\begin{array}{l}\text { Human papillomavirus } \\
\text { (HPV2: females only; HPV4: males and females) }\end{array}$ & $\begin{array}{l}11-12 \text { years } \\
(3 \text { dose series })\end{array}$ & & & \\
\hline $\begin{array}{c}\text { Meningococcal } \\
\text { (Hib-MenCY > } 6 \text { weeks, } \\
\text { MenACWY-D > } 9 \text { months; } \\
\text { MenACWY-CRM > } 2 \text { month) }\end{array}$ & $11-12$ years & & & \\
\hline
\end{tabular}

${ }^{1}$ Source: Adapted from https://www.cdc.gov/. 
toxoids and pertussis vaccine (DPT), poliovirus vaccine, Haemophilus influenzae type b (Hib) vaccine; and 1 or more doses against measles virus [2].

The past decade witnessed substantial declines in cases, hospitalizations, mortality and health-care costs due to vaccine-preventable illness [4], with new ones introduced covering rotavirus, quadrivalent meningococcal conjugate, herpes zoster, pneumococcal conjugate, and human papillomavirus infection, as well as tetanus, diphtheria, and acellular pertussis vaccine for adults and adolescents, bringing to 17 the number of diseases targeted by U.S. immunization policy. One economic analysis [5] showed that vaccination of each U.S. birth cohort with the current childhood immunization schedule feasibly prevented approximately 42,000 deaths and 20 million disease cases, with a net saving of $\$ 14$ billion in direct costs and $\$ 69$ billion in societal costs [1]. The pneumococcal conjugate and rotavirus vaccines, introduced in the past decade, prevented an estimated 13,000 deaths and up to 60,000 hospitalizations respectively each year. Advances achieved in the older hepatitis A and B, and varicella vaccines brought reported cases up to record low levels, reducing age-adjusted mortality in deaths per million population from hepatitis A from 0.38 by the end of the previous century to 0.26 by the end of the recent decade [6].

Expanded vaccination coverage has also been the most cost-effective means of advancing global welfare and one of the 10 major public health achievements worldwide in the past decade [7], with an estimated prevention of 2.5 million deaths each year among children $<5$ years through use of measles, polio, and DPT vaccines [1]. Polio eradication efforts through mandatory vaccination decreased the number of countries from 20 to four, with fewer than 1500 cases reported in 2010. With the number of countries employing hepatitis B vaccine increasing from 107 in 2000 to 178 in 2009, and global vaccination coverage of $70 \%$, at least 700,000 deaths were averted in annual birth cohorts in 178 countries [1]. From 2000 to 2009, the number of countries using the Hib vaccine worldwide increased from 62 to 161, with a resulting global coverage of 38\%, averting 130,000 pneumonia and meningitis-related deaths annually among children $<5$ years of age [1].

The combined achievements in vaccine-preventable diseases have mirrored modifications in the public health system [1]. These included the greater quantitative capacity of epidemiology in both study designs and period health surveys, methods of data collection that evolved from simple measures of disease prevalence to complex studies of precise analysis available in cohort, case-control, and randomized clinical trials to establish the efficacy of vaccination and demonstrate its low risk [1] [2]. The CDC, which assumes responsibility for collecting and publishing notifiable diseases, tracks more than 52 infectious illnesses. Public health efforts enjoining federal, state, county, local governmental health departments, and nongovernmental organization interact effectively to track infectious illness in the U.S. and rates of childhood vaccination.

\section{Categories of Vaccines}

Vaccines can be divided by the way they are prepared and therefore how they 
confer immunity, including live-attenuated, inactivated, subunit, conjugate and toxoids [1] [8].

Live-attenuated: Most frequently used for viruses rather than bacterial illnesses, the method for preparing live-attenuated vaccines involves passing the viral agent through a succession of cell cultures to weaken it producing a form that is no longer able to replicate in human cells [1]. Still recognized by the body's immune system, it protects against future infection. Examples include MMR, varicella, and Hib vaccines. Although uncommon, it is plausible that the introduced virus can cause illness if it has transformed into a more virulent form through mutation.

Inactivated: heat, irradiation, or certain chemicals to no longer cause illness upon vaccination inactivate the microbe without altering its immune activation properties in examples of poliovirus and hepatitis A vaccine. However, a disadvantage is the need for multiple boosters to augment efficacy.

Subuit: When only a portion of the microbe as antigen for immune surveillance is needed by the body to confer immunity, subunit vaccination is an appropriate methodology as for example in influenza and hepatitis B subunit vaccines [1].

Conjugate: These types of vaccines are prepared from parts of the bacterium combined with a carrier protein which when chemically linked together to bacteria coat derivatives, generate a more potent host immune response, as for example in the pneumococcal vaccine [1].

\section{Domestic and Global Vaccination Programs}

Vaccination programs in the U.S. have generally been tied to school entry. The first national push to ensure that every state in the country had vaccination requirements for children entering schools occurred in the 1970s predicated on measles outbreaks during the preceding two decades [1] [9]. Some states acted on their own accord and enacted vaccination laws. Public opinion has sometimes been an effective catalyst especially among outbreaks that remind us of the devastating potential of certain diseases that have disappeared from public view because of their infrequent occurrence. Indeed, a major advance in global public health was the launch of the World Health Organization's (WHO) Expanded Program on Immunization that promoted a schedule of basic vaccines for the immunization against polio, measles, tuberculosis, diphtheria, pertussis, and tetanus (DPT), according to the standard schedule similar to childhood programs in the U.S. [1] (Table 2).

Vaccination as a method of disease prevention is widely accepted globally. Goal 4 of the United Nations Millennium Development Goals (MDG) to reduce childhood mortality focuses on the delivery of effective vaccinations for children under the age of five [10]. Measles vaccination prevented nearly 15.6 million deaths worldwide between 2000 and 2013. The number of globally reported measles cases declined by $67 \%$ during the same period, with $84 \%$ of children worldwide receiving at least one dose of measles containing vaccine in 2013 up 
Table 2. WHO schedules of infant and childhood vaccinations ${ }^{1}$.

\begin{tabular}{|c|c|c|c|c|}
\hline VACCINE NAME & AGE AT $1^{\text {st }}$ DOSE & AGE AT $2^{\text {nd }}$ DOSE & AGE AT $3^{\text {rd }}$ DOSE & AGE AT $4^{\text {th }}$ DOSE \\
\hline BCG & B & & & \\
\hline Hepatitis B (Option 1) & B & 4 weeks & 8 weeks & \\
\hline Hepatitis B (Option 2) & B & 4 weeks & 8 weeks & 12 weeks \\
\hline Polio (OPV + IPV) & 6 weeks & 10 weeks & 14 weeks & \\
\hline Polio (IPV/OPV Sequential) & 8 weeks & 12 - 16 weeks & $\begin{array}{l}4 \text { - } 8 \text { weeks } \\
\text { after } 2^{\text {nd }} \text { dose }\end{array}$ & $\begin{array}{l}4 \text { - } 8 \text { weeks } \\
\text { after } 3^{\text {rd }} \text { dose }\end{array}$ \\
\hline Polio (IPV) & 8 weeks & 12 - 16 weeks & $\begin{array}{l}4-8 \text { weeks } \\
\text { after } 2^{\text {nd }} \text { dose }\end{array}$ & \\
\hline DTP & 6 weeks & $10-18$ weeks & $\begin{array}{l}4-8 \text { weeks } \\
\text { after } 2^{\text {nd }} \text { dose }\end{array}$ & \\
\hline Haemophilus influenzae type b (Option 1 ) & 6 weeks - 59 months & $\begin{array}{c}4 \text { weeks } \\
\text { after } 1^{\text {st }} \text { dose }\end{array}$ & $\begin{array}{c}4 \text { weeks } \\
\text { after } 2^{\text {nd }} \text { dose }\end{array}$ & \\
\hline Haemophilus influenza type b (Option 2) & 6 weeks - 59 months & $\begin{array}{l}8 \text { weeks after } 1^{\text {st }} \\
\text { dose if } 2 \text { doses, } \\
4 \text { weeks after } 1^{\text {st }} \\
\text { dose if } 3 \text { doses }\end{array}$ & $\begin{array}{c}4 \text { weeks } \\
\text { after } 2^{\text {nd }} \text { dose }\end{array}$ & \\
\hline Pneumococcal (conjugate) (Option 1) & 6 weeks & 10 weeks & 14 weeks & \\
\hline Pneumococcal (conjugate) (Option 2) & 6 weeks & 14 weeks & & \\
\hline Rotavirus (Rotarix) & 6 weeks & 10 weeks & & \\
\hline Rotavirus (Rota Teq) & 6 weeks & 10-16 weeks & $\begin{array}{c}4 \text { weeks } \\
\text { after } 2^{\text {nd }} \text { dose }\end{array}$ & \\
\hline Measles & 9 or 12 months & $\begin{array}{c}4 \text { weeks } \\
\text { after } 1^{\text {st }} \text { dose }\end{array}$ & & \\
\hline Rubella & 9 or 12 months & & & \\
\hline $\mathrm{HPV}$ & $\begin{array}{l}\text { As soon as possible } \\
\text { from } 9 \text { years old }\end{array}$ & $\begin{array}{l}6 \text { months } \\
\text { after } 1^{\text {st }} \text { dose }\end{array}$ & & \\
\hline
\end{tabular}

${ }^{1}$ Source: Adapted from http://www.who.int/en/.

$73 \%$ from 2000 [10]. Chasing a disease down to the last few cases in underdeveloped countries to levels of the developed world remains a challenge. The goal of malaria eradication faltered in the 1960s due to the resistance of Plasmodium falciparum to antimicrobial therapy and the development of mosquito vector resistance to insecticides leading to an increase in cases worldwide. All vaccines against Plasmodium falciparum (RTS, S/AAS01) were designed using genetic sequences derived from a single well-characterized reference strain of West African origin (3D7) [11]. A multivalent version of RTS, with carefully chosen sporozoite protein variants combined with additional antigens offers broader protection [12].

While most of the record decline of childhood infectious disease is attributable to increase in the use of vaccines, a small but significant minority of parents in the U.S. oppose the use of vaccines on children [1]. The less than perfect effectiveness of certain U.S. vaccination programs such as childhood pertussis and measles that depend upon widespread acceptance, resulted in a record number of cases in the U.S. 2015 [13]. 
Valuable lessons have been learned from worldwide campaigns to eradicate polio [1]. In 1988, the World Health Assembly endorsed the goal of eradication of polio at a time when the number of new cases of paralysis approximated 350,000 and the disease was endemic in 125 countries [1] [14]. The March of Dimes was created in the U.S. to end the polio epidemic that plagued the nation. To ensure efficacy against wild poliovirus infection, investigators achieved strain-specific protective immunity based upon the inherent genetic diversity of the poliovirus [15]. With the last naturally occurring case detected in 1999, wild-type poliovirus type 2 has since been eradicated in the U.S. with the last naturally occurring case detected in 1999, while type 3 is close to eradication with virtually no new detected cases. Type 1 poliovirus emerged during a 2011 outbreak in China suggesting that eradication was incomplete. More recently, cases of polio have been diagnosed in Syria, Nigeria, and Bangladesh due to the disruption of populations by war and anti-vaccine sentiment expressed by some ultra-religious Muslims [1]. As long as the poliovirus circulates anywhere in the world, there is the potential for poliomyelitis to be exported to countries that are disease-free causing serious outbreaks [1].

\section{Legal Challenges to Vaccination}

The hesitation to vaccinate children continues in the U.S. with exceptions granted from school-entry immunization mandates based upon personal beliefs and non-medical reasons [1]. Buttenheim and colleagues [16] noted that while still below levels to maintain herd immunity against measles, there was a 2- to 10 -fold underestimate of the true rate of vaccine refusal based upon personal beliefs on school-entry. This suggests inadequate understanding by parents as to the public necessity of measles immunization and fear of the vaccine that it may be pathogenic in one form or another.

With outbreak of measles cases reported by the CDC in December 2014 at Disneyland in Orange County, California [17] it was subsequently noted that 7\% of children received two or more MMR vaccinations, $45 \%$ were unvaccinated, and $43 \%$ had an unknown vaccination status [18]. These findings led two California State Senators with personal ties to health policy, one a pediatrician and the other the son of a polio survivor, to cosponsor Bill SB 277 eliminating all non-medical vaccine exemptions.

However, there was no greater challenge for public health educators than in trying to amend the misunderstanding of the risk of autism following MMR vaccination among concerned lay parent groups at the turn of the 20th century in the United Kingdom (UK). The basis for this misconception in causality was grounded in later retracted publications of a UK investigator who drew attention to cohorts of autistic children presumed to be a result of immune conditioning by early live-attenuated measles vaccination [19] [20] [21]. More than a decade later, a retracted U.S. publication cited heightened risk for autism among only African-American boys [22] citing a reanalysis of CDC data reported earlier showing no relation of autism in a population of school-matched subjects [23]. 
A recent meta-analysis [24] of case-control and cohort studies found no strong evidence for a causal effect of autism due to MMR vaccination. Other examples of the legal challenge to vaccination were seen in Mississippi [25], a state that consistently led to U.S. with vaccination rates $>99 \%$ for MMR in entering schoolchildren. There are legal precedents for the right of states to mandate vaccination for school entry to protect the public at large, both as a social obligation to provide herd immunity, and to protect those who cannot be vaccinated. It is thus safer to be unvaccinated living in a highly vaccinated community than to be vaccinated but living in an unvaccinated one [26].

Lawmakers and the lay public will continue to voice their opinions guided by the scientific community in support of necessary vaccinations, leaving aside ones with intolerable side effects such as the Lymerix vaccine that was voluntarily withdrawn after demonstrating adverse neurological sequela. Whether the lay public can accept the anticipated impact of a 1 in a million anticipated severe neurological side effect from influenza vaccination resulting in a serious neurologic development such as peripheral neuropathy remains a persistent challenge. Such occurrences foster the scientific community to continue to strive to develop more effective and safer approaches to vaccination.

\section{Assessing the Impact of Vaccines for Endemic Infection}

The assessment of the impact of vaccination on an individual or population requires an analysis of both the direct and indirect effects of immunization [27]. The theoretical concept of vaccine efficacy describes the individual level benefit or how much less likely an individual is to acquire infection following a given exposure [1] [27]. Most clinical trials however assess vaccine effectiveness at the population level [1] [27] however the indirect effect of vaccination accounting for the reduction in transmission to unvaccinated subjects in the wider population may go unnoted [1] [27]. It is the combination of direct and indirect effects that should interest public health experts in fully evaluating vaccination impact since there may be little known about the apparent or real vaccine impacts, as well as the risk of reinfection and mechanism of protection [1] [27]. Halloran and colleagues [28] used the terms leaky, all-or-nothing, or waning vaccine to describe their apparent success and biology. Farrington and colleagues [29] cited the vaccine for pertussis as a leaky vaccine, while those for measles and rubella were all-or-nothing, and the cholera was a waning type. Magpantay and colleagues [30] added mathematical modelling to extrapolate the epidemiological efficacy and ramifications of such imperfect vaccines considering that an imperfect vaccine might exhibit failures in degree or leakiness and take or all-or-nothingness. Edlefsen [31] noted that such a simple dichotomy could have serious implications for analysis of methodologies since leaky vaccines in effect protected highly exposed recipients at a lower rate, and could induce a violation of the proportional hazards condition. The latter was often assumed in survival analysis due to a changing fraction of at-risk subjects over time in both vaccinated and unvaccinated individuals. 


\section{Microeconomic Impact of Vaccination}

Jit and coworkers [32] analyzed the economic impact of vaccination. The authors noted that investment in immunization programs dramatically increased in developed and developing countries over the past two decades because of the development of new vaccines against major diseases [33], and the emergence of new financing mechanisms. Organizations such as Gavi, the Vaccine Alliance that subsidize the cost of vaccines for some lesser-developed countries and the Pan American Health Organization contributed to there economic feasibility and success of vaccination programs [34]. Spending growth heightened the importance of investing in immunization [35].

Microeconomic evaluations can be employed to facilitate decision-making by national and multinational stakeholders through comparisons of the economic cost of implementing vaccine program infrastructure, purchase, and delivery, against the health and economic benefits of vaccination. Economists have argued that improvements in health can lead to economic growth by decreasing fertility, strengthening macroeconomic stability, and improving educational outcomes [32] [36] [37]. Other beneficial aspects included the accrued benefits of health gains, health-care cost savings, reductions in the time costs of caring for the sick, improved economic productivity due to prevention of mental and physical disabilities and child survival, as well as, the development of herd immunity, and prevention of antibiotic resistance [1]. Bishai and coworkers [38] noted a significant reduction in the poverty-related gradient in under-five mortality by measles vaccination improving health equity directly. Using a cost-benefit analysis approach to assess the impact of Haemophilus influenzae type b vaccination, Bärnighausen and colleagues [39] demonstrated that past economic evaluations had mostly adopted narrow evaluation perspectives, focusing primarily on health gains, health-care cost savings, and reductions in the time costs of caring, while usually ignoring other important benefits. The latter include outcome-related productivity gains [improved economic productivity due to prevention of mental and physical disabilities], behavior-related productivity gains [economic growth due to fertility reductions as vaccination improves child survival], and community externalities [herd immunity and prevention of antibiotic resistance] [1].

While vaccination is most cost-effective in low-income groups, their benefits may be the most difficult to ascertain leading to exacerbation or narrowing of the indicators of equity. Rheingans and colleagues [40] estimated distributional effects of rotavirus vaccination in 25 Gavi countries noting that the greatest potential benefit of rotavirus vaccination in Gavi countries were in the poorest quintiles while existing trends were skewed towards the richest quintiles. Maximizing health benefits for the poorest children while assuring the best value-for-money may require increased attention to these distributional effects.

Verguet and colleagues [41] hypothesized that public financing of rotavirus vaccination in India and Ethiopia with an estimated $4 \%$ of global child deaths or approximately 300,000 death, attributed to rotavirus in 2010 , could substantially 
decrease child mortality and rotavirus-related hospitalizations, prevent healthrelated impoverishment and bring significant cost savings to households. Using extended cost-effectiveness analysis to evaluate a hypothetical publicly financed program for rotavirus vaccination, their analyses showed direct benefits of rotavirus vaccination in substantially decreasing rotavirus deaths mainly among the poorer, with reduced household expenditures across all income groups, and effective provision of financial risk protection concentrated among the poorest. Notwithstanding, the potential indirect benefits of vaccination of herd immunity would lead to increased program benefits among all income groups.

\section{Conclusion}

Mass-vaccination campaigns have lowered the incidence of measles, mumps, and rubella in lesser developed countries to low levels but that may not be good enough since these diseases like others, can recur. Two big improvements underscore the argument for wider eradication and prevention campaigns, in a list of communicable diseases including better techniques for locating and monitoring cases of global diseases, and improved medical technology to produce superior vaccines. The scientific community will guide political and lay public attitudes to effectively deal with the most serious threats to our public health through vaccination.

\section{Disclose}

The Author has nothing to disclose.

\section{References}

[1] Younger, D.S., Younger, A.P.J. and Guttmacher, S. (2016) Childhood Vaccination. Implications for Global and Domestic Public Health. Neurologic Clinics, 34, 1035 1047. https://doi.org/10.1016/j.ncl.2016.05.004

[2] CDC (1999) Ten Great Public Health Achievements-United States, 1990-1999. MMWR Morbidity and Mortality Weekly Report, 48, 241-264.

[3] CDC (1998) National, State, and Urban Area Vaccination Coverage Levels among Children Aged 19-35 Months-United States, 1997. MMWR Morbidity and Mortality Weekly Report, 47, 547-554.

[4] CDC (2011) Ten Great Public Health Achievements-United States, 2001-2010. MMWR Morbidity and Mortality Weekly Report, 60, 619-623.

[5] Zhou, F. (2011) Updated Economic Evaluation of the Routine Childhood Immunization Schedule in the United States. The 45 th National Immunization Conference, Washington DC, 28-31 March 2011.

[6] Vogt, T.M., Wise, M.E., Bell, B.P., et al. (2008) Declining Hepatitis A Mortality in the United States during the Era of Hepatitis A Vaccination. The Journal of Infectious Diseases; 197, 1282-1288. https://doi.org/10.1086/586899

[7] CDC (2011) Ten Great Public Health Achievements-Worldwide, 2001-2010. MMWR Morbidity and Mortality Weekly Report, 60, 814-818.

[8] Hussein, I.H., Chams, N., Chams, S., et al. (2015) Vaccines through Centuries: Major Cornerstones of Global Health. Front Public Health, 3, 269. 
[9] Lantos, J.D., Jackson, M.A. and Harrison, C.J. (2012) Why We Should Eliminate Personal Belief Exemptions to Vaccine Mandates. Yale Journal of Health Policy, Law, and Ethics, 37, 131-140. https://doi.org/10.1215/03616878-1496038

[10] http://www.un.org/millenniumgoals/2015 MDG Report/pdf/MDG\%202015\%20rev \%20(July\%201).pdf

[11] Plowe, C.V. (2015) Vaccine-Resistant Malaria. New England Journal of Medicine, 373, 2082-2083. https://doi.org/10.1056/NEJMe1511955

[12] Heppner, D.G., Kester, K.E., Ockenhouse, C.F., et al. (2005) Towards an RTS, S-Based, Multi-Stage, Multi-Antigen Vaccine against Falciparum Malaria: Progress at the Walter Reed Army Institute of Research. Vaccine, 23, 2243-2250.

https://doi.org/10.1016/j.vaccine.2005.01.142

[13] Jakinovich, A. and Sood, S.K. (2014) Pertussis: Still a Cause of Death, Seven Decades into Vaccination. Current Opinion in Pediatrics, 26, 597-604. https://doi.org/10.1097/MOP.0000000000000139

[14] Mundel, T. and Orenstein, W.A. (2013) No Country Is Safe without Global Eradication of Poliomyelitis. Editorial. New England Journal of Medicine, 369, 2045-2046. https://doi.org/10.1056/NEJMe1311591

[15] Plowe, C.V. (2015) Vaccine-Resistant Malaria. New England Journal of Medicine, 373, 2082-2083. https://doi.org/10.1056/NEJMe1511955

[16] Butterheim, A.M., Sethuraman, K., Omer, S.B., et al. (2015) MMR Vaccination Status of Children Exempted from School-Entry Immunization Mandates. Vaccine, 33, 6250-6256. https://doi.org/10.1016/j.vaccine.2015.09.075

[17] Clemmons, N.S., Gastanaduy, P.A., Fiebelkorn, A.P., et al. (2015) Measles-United States, January 4-April 2, 2015. Morbidity and Mortality Weekly Report, 64, 373-376.

[18] Zipprich, J., Winter, K., Hacker, J., et al. (2015) Measles Outbreak-California, December 2014-February 2015. Morbidity and Mortality Weekly Report, 64, 153-154.

[19] Wakefield, A.J., Murch, S.H., Anthony, A., et al. (1998) Ileal-Lymphoid-Nodular Hyperplasia, Non-Specific Colitis, and Pervasive Developmental Disorder in Children. Lancet, 351, 637-641. https://doi.org/10.1016/S0140-6736(97)11096-0

[20] Wakefield, A.J., Anthony, A., Schepelmann, S., et al. (1998) Persistent Measles Virus Infection and Immunodeficiency in Children with Autism, Ileocolonic Lymphoid Nodular Hyperplasia and Non-Specific Colitis. Gut, 42, A86.

[21] Wakefield, A.J. and Montgomery, S.M. (1999) Autism, Viral Infection and Measles-Mumps-Rubella Vaccination. Israel Medical Association Journal, 1, 183 187.

[22] Hooker, B.S. (2014) Measles-Mumps-Rubella Vaccination Timing and Autism among Young African-American Boys: A Reanalysis of CDC Data. Transl Neurodegeneration, 3, 16. https://doi.org/10.1186/2047-9158-3-16

[23] DeStefano, F., Bhasin, T.K., Thompson, W.W., Yeargin-Allsopp, M. and Boyle, C. (2004) Age at First Measles-Mumps-Rubella Vaccination in Children with Autism and School-Matched Control Subjects: A Population-Based Study in Metropolitan Atlanta. Pediatrics, 113, 259-266. https://doi.org/10.1542/peds.113.2.259

[24] Taylor, L.E., Swerdfeger, A.L. and Eslick, G.D. (2014) Vaccines Are Not Associated with Autism: An Evidence-Based Meta-Analyses of Case-Control and Cohort Studies. Vaccine, 32, 3623-3629. https://doi.org/10.1016/j.vaccine.2014.04.085

[25] Cawkwell, P.B. and Oshinsky, D. (2015) Childhood Vaccination Requirements: Lessons from History, Mississippi, and a Path Forward. Vaccine, 33, 5884-5887. https://doi.org/10.1016/j.vaccine.2015.08.087 
[26] Lantos, J.D., Jackson, M.A. and Harrison, C.J. (2012) Why We Should Eliminate Personal Belief Exemptions to Vaccine Mandates. Journal of Health Politics, Policy and Law, 37, 131-140. https://doi.org/10.1215/03616878-1496038

[27] Raggonet, R., Trauer, J.M., Denholm, J.T., et al. (2015) Vaccination Program for Endemic Infections: Modellling Real versus Apparent Impacts of Vaccine and Infection Characteristics. Scientific Reports, 5, 15468.

https://doi.org/10.1038/srep15468

[28] Halloran, M.E., Haber, M. and Longini, I.M. (1992) Interpretation and Estimation of Vaccine Efficacy under Heterogeneity. American Journal of Epidemiology, 136, 328-343.

[29] Farrington, C.P. (2003) On Vaccine Efficacy and Reproduction Numbers. Mathematical Biosciences, 185, 89-109. https://doi.org/10.1016/S0025-5564(03)00061-0

[30] Magpantay, F.M., Riolo, M.A., DE Cellès, M.D., et al. (2014) Epidemiological Consequences of Imperfect Vaccines for Immunizing Infections. Journal of Applied Mathematics, 74, 1810-1830.

[31] Edlefsen, P.T. (2014) Leaky Vaccines Protect Highly Exposed Recipients at a Lower Rate: Implications for Vaccine Efficacy Estimation and Sieve Analysis. Computational and Mathematical Methods in Medicine, 2014, Article ID: 813789. https://doi.org/10.1155/2014/813789

[32] Jit, M., Hutubessy, R., Png, M.E., et al. (2015) The Broader Economic Impact of Vaccination: Reviewing and Appraising the Strength of Evidence. BMC Medicine, 13, 209. https://doi.org/10.1186/s12916-015-0446-9

[33] Plotkin, S.A. (2005) Vaccines: Past, Present and Future. Nature Medicine, 11, S5-S11. https://doi.org/10.1038/nm1209

[34] Leach-Kemon, K., Graves, C.M. and Johnson, E.K., et al. (2014) Vaccine Resource Tracking Systems. BMC Health Services Research, 14, 421. https://doi.org/10.1186/1472-6963-14-421

[35] Kim, S.-Y. and Goldie, S.J. (2008) Cost-Effectiveness Analyses of Vaccination Programmes: A Focused Review of Modelling Approaches. Pharmacoeconomics, 26, 191-221. https://doi.org/10.2165/00019053-200826030-00004

[36] Bloom, D.E., Canning, D. and Jamison, D.T. (2004) Health, Wealth, and Welfare. Finance and Development, 41, 10-15.

[37] Belli, P.C., Bustreo, F. and Preker, A. (2005) Investing in Children's Health: What Are the Economic Benefits? Bulletin of the World Health Organization, 83, 777-784.

[38] Bishaia, D., Koenig, M. and Khan, M. (2003) Measles Vaccination Improves the Equity of Health Outcomes: Evidence from Bangladesh. Health Economics, 12, 415-419. https://doi.org/10.1002/hec.732

[39] Bärnighausen, T., Bloom, D. and Canning, D. (2011) Rethinking the Benefits and Costs of Childhood Vaccination: The Example of the Haemophilus Influenzae Type B Vaccine. Vaccine, 29, 2371-2380. https://doi.org/10.1016/j.vaccine.2010.11.090

[40] Rheingans, R., Atherly, D. and Anderson, J. (2012) Distributional Impact of Rotavirus Vaccination in 25 GAVI Countries: Estimating Disparities in Benefits and Cost-Effectiveness. Vaccine, 30, A15-A23.

https://doi.org/10.1016/j.vaccine.2012.01.018

[41] Verguet, S., Murphy, S., Anderson, B., et al. (2013) Public Finance of Rotavirus Vaccination in India and Ethiopia: An Extended Cost-Effectiveness Analysis. Vaccine, 31, 4902-4910. https://doi.org/10.1016/j.vaccine.2013.07.014 
Submit or recommend next manuscript to SCIRP and we will provide best service for you:

Accepting pre-submission inquiries through Email, Facebook, LinkedIn, Twitter, etc. A wide selection of journals (inclusive of 9 subjects, more than 200 journals)

Providing 24-hour high-quality service

User-friendly online submission system

Fair and swift peer-review system

Efficient typesetting and proofreading procedure

Display of the result of downloads and visits, as well as the number of cited articles Maximum dissemination of your research work

Submit your manuscript at: http://papersubmission.scirp.org/

Or contact wijns@scirp.org 